\title{
Kitekintés
}

GIMES JÚLIA GONDOZÁSÁBAN

\section{RÁKPUSZTÍTÓ NANO-ORIGAMI}

Amerikai és kínai kutatók olyan nanorobotot fejlesztettek ki, amely daganatos állatokban megtalálta a tumorokat, és jelentősen csökkentette a méretüket.

Az önmagát hajtogatni képes, a hajszál vastagságánál ezerszer kisebb, néhány tíznanométeres mérettartományba eső DNS-origamiról azt állítják: fejlesztésében az áttörés az, hogy megoldották a nanorobotok korábbi szelektivitási problémáját. Az új „készülék” már csak a rákos sejteket támadja meg. Felszínén ugyanis olyan fehérjét szállít, amely szelektíven kötődik a csak a daganatos sejteken megjelenő nukleolin nevü fehérjéhez. Pusztító hatását pedig egy másik általa szállított anyaggal, a trombinnal éri el. A trombin nevü enzim a normális véralvadási folyamatok egyik kulcsszereplöje. Ebben az esetben mintegy megalvasztja a daganat ereiben keringő vért. Ezzel elzárja a tumor tápanyagellátását biztosító ereket. A daganat körül mintegy összegyülnek a parányi DNS-robotok, és szinte egyszerre intéznek ellene támadást.

A rendszert az állatokon többféle daganatos betegségben tesztelték: emlö-, petefészek- és tüdőrákban, illetve melanomában. A legjobb eredményeket a festékes bőrdaganat, a melanoma esetén érték el, ahol a túlélési idő több mint kétszeresére nőtt, és a nanorobotos kezelés az áttétek kialakulását is megakadályozta.

A kutatók nem tapasztalták, hogy a nanorobotok ellen az immunrendszer támadást intézett volna (ezt Bama törpemalacokon is tesztelték), és nem fordult elö az sem, hogy a robotok bejutva az agyba vagy a szív ereibe, agyi vagy szívizominfarktust okoztak volna. Szerintük az eljárás biztonságos, és nagy jövő elött áll. Elvileg ugyanis az összes szolid tumor esetén alkalmazható lenne, és a kezelési stratégiának megfelelően változtatni lehetne azt a hatóanyagot, melyet a nanorobot trójai falóként a daganat ellen bevet. Esetleg más-más gyógyszert szállító miniatürök egyidejüleg is alkalmazhatók lesznek.

Csao Csüliang (Yuliang Zhao) és munkatársai most partnereket keresnek a további klinikai fejlesztésekhez.

Li, S. - Jiang, Q. - Liu, S. et al.: A DNA Nanorobot Functions as a Cancer Therapeutic in Response to a Molecular Trigger in vivo. Nature Biotechnology, 2018; DOI: 10.1038/ nbt.4071 


\section{AZ AGY BETEGSÉGEI ÉS A GÉNEK}

Hogyan okoznak a genetikai eltérések pszichiátriai betegségeket? Ennek a kérdésnek a megválaszolásához próbáltak közelebb jutni amerikai, dán és kínai kutatók.

Munkájuk során olyan elhunytak agyszövetein végeztek a gének aktivitását elemző vizsgálatokat, akik életükben autisták voltak, illetve skizofréniában, bipoláris betegségben, depresszióban vagy alkoholizmusban szenvedtek.

Az első három betegség esetén nagy átfedés volt a génaktivitási mintázatok között. A kutatók megállapították, hogy közös jellegzetesség egyebek között a neuronok növekedését serkentő csillagsejtek működését szabályozó gének magas aktivitása.

A „depressziós agy” mintázatai eltértek a többitől, és stresszel, valamint gyulladásos folyamatokkal kapcsolatos jeleket mutattak. Ezek az eredmények alátámasztják azokat a korábbiakat, amelyek alapján már felmerült, hogy a depresszió kezelésében esetleg gyulladáscsökkentő szerek alkalmazása is hatékony lehet.

Az alkoholizmus génmintázata egyáltalán nem mutatott átfedést más kórképekkel. Ennek oka az alacsony mintaszám is lehet, és természetesen az is, hogy a függőség alapvetően másként változtatja meg a gének aktivitását, mint a többi kórkép.

Gandal, M. J. - Haney, J. R. - Parikshak, N. N. et al.: Shared Molecular Neuropathology across Major Psychiatric Disorders Parallels Polygenic Overlap. Science, 09 Feb 2018. 359, 6376, 693-697. DOI: 10.1126/science.aad6469, http://science.sciencemag.org/ content/359/6376/693.full

\section{VÍZOLDHATÓ NANOGRAFÉN}

A grafén, a kétdimenziós, egy atomréteg vastagságú grafit és az úgynevezett nanografén (amelynek a vastagság mellett másik kiterjedése is az 1 és 100 nanométer közötti nagyságrendbe esik) kivételes mechanikai, elektromos és optikai tulajdonságokkal rendelkeznek. Mindezek alapján változatos felhasználási lehetőségeik adódnának, azonban ezek egy részét a grafének vízben való rossz oldhatósága megvalósíthatatlanná teszi. Japán kutatóknak most sikerült vízoldható nanografén-struktúrákat elóállítaniuk, és ez megnyithatja az utat például a fotodinamikus rákterápiában történő felhasználás irányába.

A lebontásos technika, melynek során a graféneket grafitból állítják elö, kevésbé szabályozható, a keletkező termék heterogén, összetétele bizonytalan. A kisebb, alapmolekulákból való felépítés jobban kézben tartható. Az egyik ilyen grafén-alapmolekula kémiai módosításával (bór bevitelével, majd annak tetra-etilén-glikol oldalláncot tartalmazó aromás molekulára való cserélésével) sikerült 
enyhén hajlított szerkezetű, vízben jól oldódó különleges optikai tulajdonságú nanografént elóállítani. A molekula lézerrel besugározva fluoreszkál, alapállapotban biokompatibilis és a sejtekbe bejuttatható. Lézerrel gerjesztett formája azonban megöli a sejteket, és mindez alkalmassá teheti fotodinamikus rákellenes szerként való felhasználásra.

A fotodinamikus terápia lényege, hogy a daganathoz célzottan eljuttatott anyag fény hatására pusztítani kezdi a tumorsejteket.

Lin, H.-A. - Sato, Y. - Segawa, Y. et al.: A Water-soluble Warped Nanographene: Synthesis and Applications for Photoinduced Cell Death. Angewandte Chemie, (2018) 130, 1-6. DOI: 10.1002/anie.201713387

\section{HIGH-TECH BIOLÓGIA}

Az egyiptomi gyümölcsevő denevérek (vagy más néven nílusi repülőkutyák) olyan kifinomult tájékozódási-navigációs rendszerrel rendelkeznek, amelyhez hasonlót a katonai célú felderítő drónokban is csak a legutóbbi időkben kezdtek alkalmazni. A University of Washington és a Johns Hopkins University munkatársai (féltucatnyi anyagi támogatóval, közöttük az Air Force Office of Scientific Research és az Office of Naval Research) most publikált cikkükben ismertetik ezt a különleges technikát.

A denevérek általában magas hangon füttyögnek, tájékozódásukhoz pedig a tárgyakról visszaverődő ultrahangokat használják. A gyümölcsevő egyiptomiak azonban a nyelvükkel csettintenek, és inkább a delfinekre jellemző kattanásszerü hangot hallatnak. A kutatók azt találták, hogy ezek a denevérek anélkül, hogy a fejüket vagy bármilyen más testrészüket megmozdítanák, a legkülönbözőbb irányokba képesek elküldeni ezeket a letapogató jeleket.

A nagysebességü videokamerákkal és háromdimenziós elrendezésű ultrahang mikrofonokkal berendezett denevérlaboratóriumban felvett anyagokat elemezve megállapították, hogy kísérleti alanyaik a legmodernebb frekvenciaszkennelő lokátorokhoz hasonlóan müködnek. A különböző frekvenciájú hullámokat nem egy pontból indítják, és így azok a környező tárgyakat más-más szögben érik el, és róluk más-más szögben verődnek vissza. Ennek eredményeként nagy területekről sokkal jobb felbontású képeket lehet kapni, mint a hagyományos szonárokkal.

Lee, W.-J. - Falk, B. - Chiu, C. et al.: Tongue-driven Sonar Beam Steering by a Lingualecholocating Fruit Bat. PLOS Biology, Published: 15 December 15 2017. DOI: 10.1371/ journal.pbio.2003148, http://journals.plos.org/plosbiology/article?id=10.1371/journal. pbio. 2003148 


\section{MERÉSZ FOCIÁLMOK - SZOBROKBAN}

Noha a kínai csapat idén nyáron nem lesz ott a labdarúgó világbajnokságon, az ambíciókról, a vágyakról és talán a jövőről sokat elárul, hogy az Egyesült Királyság után Kínában található a legtöbb - szám szerint 39 - focistát ábrázoló szobor. Sőt, a legnagyobb méretüt is Kínában emelték.

A University of Sheffielden folyó, a világ sportolószobrait dokumentáló projekt eredménye az a tanulmány is, amely Kína labdarúgással kapcsolatos terveit a szobrok alapján elemzi.

A müalkotások nagy részét az elmúlt tíz-tizenöt évben általában állami költségen emelték, összhangban azokkal a hivatalos kínai tervekkel, amelyek szerint labdarúgó világbajnokságot kívánnak rendezni és nyerni. Az átlag kínai állampolgárt kevéssé izgatja a foci, a szobrok nagy része sportiskolák közelében van. Az elitnevelés hagyományos kínai módszerei néhány területen már bizonyították hatékonyságukat, egyelöre azonban a labdarúgásban elmaradtak a remélt eredmények. Az ország eddigi legjelentősebb focisikere, hogy 2002-ben a válogatott bejutott a világbajnokság 32 csapatos döntöjébe. Ennek az eredménynek állít emléket a focistaszobor-méret világbajnokság kínai győztese.

A focistaszobrok, noha a sportág nem része a kínai kultúrának, jellemzőek az országra. A világ más részein zömében a sztár játékosokról készülnek a szobrok, jellemzően valami közönséget lázba hozó akció - cselezés, fejelés, gólszerzés közben. A tipikus kínai focistaszobor ismeretlen játékost ábrázol, mégpedig szerelés közben.

Stride, C. B. - Vandenberg, L.: The Art of Face-saving and Culture-changing: Sculpting Chinese Football's Past, Present and Future. Sport in Society, Published online: 31 Jan 2018. 1-26. DOI: 10.1080/17430437.2018.1430487 